\title{
The Impacts and Challenges of Pedagogical Skills Improvement Program at Adama Science and Technology University
}

\author{
Tolera Negassa \\ Asst. Prof., Arsi University, Ethiopia, toleranegassad@gmail.com
}

Ziyn Engdasew

Assoc. Prof., Adama Science and Technology University, Ethiopia, engdasewziyn1970@gmail.com

\begin{abstract}
This research report is about the impact of university teachers' pedagogical skills training on approaches to teaching measured by teaching components in ASTU. Descriptive survey research design was employed. The participants were 111 teachers attended Pedagogical Skills Improvement on seven modules for 106hrs in the year 2009-2013.Stratified sampling techniques were employed to select participants. The teachers were from six schools that were divided into five groups depending on the amount of pedagogical training they had. The instrument of data collection was questionnaire and checklists. Mixed research approach was employed to analyses of the data. The results indicated that pedagogical skills training had an effect on their teaching skills in using lesson planning, active learning, and continuous assessment and classroom management. The teachers mentioned not only positive effects of pedagogical training on their teaching but also informed some difficulties like redundancy of concepts, activities, examples; modules are not to the standard, long duration of the training and large class size, lack of material and facilities, lack of motivation, inability to implement fully what they have acquired from the training.
\end{abstract}

Keywords: pedagogy, professional development, skills, teaching, training

\section{INTRODUCTION}

Traditionally, subject expertise has been the most respected quality of a university teacher. In recent years, however, there have been discussions about the need to improve university teachers' pedagogical thinking and skills as well. As a consequence, training of university teachers has recently become a widespread trend in many countries (Postareff etal., 2007).

As Gilbert and Gibbs have revealed, there is a need to establish the effectiveness of higher education teachers' training in improving university teaching. Evidence of impact

Citation: Negassa, T., \& Engdasew, Z. (2017). The Impacts and Challenges of Pedagogical Skills Improvement Program at Adama Science and Technology University. International Journal of Instruction, 10(4), 19-38. https://doi.org/10.12973/iji.2017.1042a 
is needed to guide educational development units to design their courses since earlier research in this field is rather descriptive than evaluative (Gilbert \& Gibbs, 1999). Gibbs and Coffey (2004), examined the impact of pedagogical skills training of university teachers on approaches to teaching, teaching skills and approaches to learning of their students. Many countries, such as Norway, UK and Sri Lanka have made decisions about the compulsory pedagogical skills training of university teachers. In Finland, many universities arrange pedagogical training for their teachers, that every new teachers should have the possibility to participate in an introductory seminar on university teaching in order to improve teachers' pedagogical thinking and skills.

The Ethiopian higher education reform anticipates the provision of a quality and relevant education in HEIs. The reform has also recommended the establishment of Pedagogical Resource Centers (PRC) and pedagogical skills improvement institution as another means of ensuring quality. A Pedagogical Resource and Training Center has in some institution, focused on issues of how teachers organize their work, how they use available resources, understand purposes of the education offered, determine the desired learning outcomes, design the right course content, and organize the teaching-learning process. In the current trend HE has stressed active learning, exploitations of teaching aids, ICT and new teaching-learning methods, as well as preparation of teaching materials, curricula development and review.

In Ethiopia, to improve teacher's quality, a national Agency for Quality and Relevance Assurance was established by proclamation and has started its work (FDRE, 2005). Accordingly, Ministry of Education established Teacher Education System Overhaul (TESO) as a subcommittee to sort out the problem. TESO found that Ethiopian Teachers are failed to impart the quality education due to the lack of appropriate kind of preservice or in-service pedagogical training to develop his knowledge, skill and abilities (Hunde, 2008). Consequently, TESO designed a special curriculum material as per Ethiopian Education policy (FDRE, 2004). In order to provide training, as per the newly designed curriculum, HDP was introduced for HEI instructors.

The aim of the Higher Diploma Program (HDP) is to create a reflective teacher. Dewey (1933) recognized the value of reflection in education. According to Dewey, reflection ('reflective thought/thinking') involves 'active, persistent and careful consideration of any belief or supposed form of knowledge' and 'turning a subject over in the mind and giving it serious and consecutive consideration'. Similarly, Boud et al. (1985) define reflection as an important human activity in which people recapture their experience, think about it. The endeavour to assess the impacts of the training in making trained instructors being reflective in their profession, challenges in the implementation, perception and attitudes towards the program become an area of focus for evaluation and feedbacks. In view of this, the study tries to evaluate the practices, impacts, prospects and challenges of the program in Pedagogical skills improvement and support training center of Adama Science and Technology University. 


\section{Problem Statement}

Adama Science and Technology University is one of the pioneers in technological university in the nation. It strives to achieve of Excellency in science and technology education as its major objectives. To this effect, Adama Science and technology university launched Higher Diploma Program(HDP) and latter improve the name as Pedagogical Skill Improvement and Support Training ( PSIST) with the major objective of acquainting teachers to be aware and implement modern methods of teaching so as to improve the quality of education. The Pedagogical skills training promote instructors to involve in practical training and support their skills to use modern and active learning methods and be reflective practitioners in education.

The HDP training program has been offered at Adama Science and Technology University commencing in 2003. Approximately more than 600 instructors were graduated in the HDP class and latter PSIST training in the last 10 years. The Pedagogical Skill Improvement and Support (PSIST) is developed under the "School of pedagogy" in 2008 to meet the needs of teachers and support the implementation of the "Setting -Up Adama University Framework". The Pedagogical Skill Improvement and Support being delivered for all teaching staff, accepted as compulsory training. It provides teachers with a practical training to support their development as effective teachers and reflective practitioners with enhanced professional status, be able to model active learning and continuous assessment, manage change and make a difference in the education system.

The training course emphasizes the use of teaching strategies and practices, which integrate technology into the existing curriculum. The training aims to enhance teacher productivity and enable them to create technology-enhanced learning activities and to utilize the computer skill as an information resource and a communication tool. The Pedagogical Skill Improvement and Support is standardized across all Schools and has the flexibility to be related to the school discipline, subject specialism and particular interests of the candidates. It is based on practice, both in the university, schools, TVETs, Health institutions and industries in accordance with the specializations of candidates.

The Pedagogical Skill Improvement and Support for teachers in each school work as a group, supported by trainers and advisor/s. It lasts for six months and provides time for attending Pedagogical Skill Improvement and Support sessions, observations and feedbacks, interviews with candidates, real life situations in industries, action research, and professional meetings with the trainers.

Teachers have to complete a number of activities showing that their work for the training has had a significant impact on changing their own teaching. Throughout the training duration, reflection on their classroom and laboratory practice and research should lead to continuing and sustainable improvement in their teaching. Continuous assessment, including self-assessment, contributes to completing the Portfolio of Evidence, which is the start of a (CPD) Continuous Professional Development plan for teachers completing the training. Literature showed that it is not only the training 
program which can create a quality teacher but individual characteristics also play an important role. UNESCO (1994) made an international recommendation that teachers' attitudes, beliefs, expectations and acceptance towards teacher training programme will decide its effectiveness. Hence it is found to be imperative and timely to evaluate the achievements stated above and identifying the barriers for its effective realization into practices and forward some feasible feedback for further improvement of the program.

\section{Basic questions}

- What are the impacts of pedagogical skills training received on teachers' teaching skills at Adama Science and Technology University?

- What are the perception of trained teachers towards contents, methods, assessment and activities of the pedagogical skill training?

- What are the challenges encountered in the implementation of the pedagogical skills training?

\section{Objectives of the study}

The Pedagogical Skill Improvement has been adapted and cascaded to schools' disciple from Higher Diploma Program. This study therefore, aims to know the significant impact observed on teachers' teaching skills as a result of the training received and improve the training modules thereof.

\section{Specific objective}

This study would like to achieve the following specific objectives:

- Investigate the impact of pedagogical skills training on teachers teaching skills at Adama Science and Technology University

- Make out the perception of trained teachers towards contents, methods. Assessment and activities of the pedagogical skills training

- Identify the challenges encountered in the implementation of the pedagogical skills training and propose remedial so as to sustain the programme.

\section{Review of the Related Literature}

\section{The Concept of teaching}

Teaching is an interactive process, primarily involving classroom talk, which takes place between teacher and pupils and occurs during certain definable activities. Teaching is an interpersonal activity directed towards learning by one or more persons. Modern teaching assigns an important place to student activity (klaver, 1984). It calls for student centered approach. The most distinctive feature of modern society is its science based technology which has been making a profound impact not only on the economic and political life of a country but also on its educational system for the development of proper interests, attitudes and values.

Teaching as a process of guiding learner, deals with acquisition of knowledge, development of skills and values systems an effective means. This happens if teachers 
are capable of selecting, planning, organizing and applying the different methods and techniques of teaching .To have a good knowledge of the different methods and techniques of teaching and develop the skill of using them, teachers need to read, learn and recent finding of this matters. The materials they get and the information they exchange with their colleague are very important (Clark \& Star, 1996).

This professional development focuses on preparing teachers in pedagogical content as well as academic content. Teacher's work is undergoing rapid change: political, educational and social changes and this means that teachers need more and better Continuous Professional Development (CPD) in order to keep up with the changes and remain relevant in the teaching profession. The quality of teachers is of great importance, as changing needs place greater pressures on teachers such as having to deal with the challenge of large classes and learners of different characteristics. This raises the need for teachers to be supported more than ever before, hence the need to step up the professional development of teachers, which is an often neglected aspect in SubSaharan Africa (Nakabugo etal. 2010).

According to Putnam and Borko, (2000) individual teachers' involvement in professional development activities can arises from an interest in lifelong learning, a sense of moral obligation, a felt need to enhance professional competence and to keep abreast of recent developments in their field of work, the need to comply with mandatory government requirements, or for career advancement. Teacher's continuous professional development takes place when favourable learning environments are provided in which teachers are responsible for their own learning whereas staff developers play an important role in creating favourable learning environments for teacher's professional learning.

\section{Active learning}

Most of the time, in a typical classroom setting, students are involved only passively in learning, i.e., in listening to the instructor, looking at the occasional overhead or slide, and reading (when required) the text book. Research shows that such passive involvement generally leads to a limited retention of knowledge by students.

Defining "active learning" is a bit problematic. The term means different thing to different people, while for some the very concept is redundant since it is impossible to learn anything passively. Certainly this is true, but it doesn't get very far toward understanding active learning and how it can be applied in college classrooms (Scott, 2005).

Active learning is engaging students in doing something besides listening to a lecture and taking notes to help them learn and apply course material. Students may be involved in talking and listening to one another, or writing, reading and reflecting individually (Felder and Brent, 1997). We might think of active learning as an approach to instruction in which students engage the material they study through reading, writing, talking, listening, and reflecting. Active learning stands in contrast to "standard" modes of instruction in which teachers do most of the talking and students are passive. 
Using active learning does not mean abandoning the lecture format, but it does take class time. Lecturers who use active learning pause frequently during the period once every fifteen minutes or so to give students a few minutes to work with the information they're providing (Scott, 2005). It means that they may ask students to respond to a question, to summarize important concepts in writing, or compare notes with a partner. For some lecture-based classes, using active learning may be a bit more challenging because of class size or room limitations such as fixed seating. Breaking students into groups under these circumstances may not be possible, but other strategies such as individual writing or paired activities are quite possible and lead to good results.

\section{Instructional assessment}

Assessment of student achievement is changing, largely because today's students face a world that will demand new knowledge and abilities Bond, Herman, \& Arter, 1994). In the global knowledge economy of the 21 st century, students will need to understand not only the basics, but also to think critically, to analyse, and to make inferences. Helping students develop these skills will require changes in assessment at the classroom level, as well as new approaches to large-scale, high-stakes assessment. Changes in the skills and knowledge needed for success, in our understanding of how students learn, and in the relationship between assessment and instruction are changing our learning goals for students and schools. Consequently, it is a must to change assessment strategies to tie assessment design and content to new outcomes.

As society shifts from an agrarian and industrial age, in which a person could get by with basic reading and arithmetic skills, to an information age, which requires the ability to access, interpret, analyse, and use information for making decisions, the skill and competence needed to succeed today workplace are changing as well (Bond, 1992). In response to these changes, content standards - the knowledge, skills, and behaviours needed for students to achieve at high levels are being developed at the national and regional state levels in areas such as mathematics, and science in particular.

In this atmosphere of reform, policymakers hope that changes in assessment will cause teachers and university to do things differently (Linn, 1987). Assessment reform is viewed as a means of setting more appropriate targets for students, focusing staff development efforts for teachers, encouraging curriculum reform, and improving instruction and instructional materials (Darling-Hammond \& Wise, 1998).

The notion that learning comes about by the accretion of little bits is outmoded learning theory. Current models of learning based on cognitive psychology contend that learners gain understanding when they construct their own cognitive maps of the interconnections among concepts and facts. Thus, real learning cannot be spoon-fed, one skill at a time." (Shepard, 1989). Although basic skills may be important goals of education, they are often over-emphasized in an effort to raise standardized test scores. Basic skills and minimum competencies become the overarching goal of schools and teachers as accountability and minimum competency exams concentrate on these areas.

However, educators, policymakers, and parents are beginning to recognize that minimums and basics are no longer sufficient (Winking \& Bond, 1995) and are calling 
for a closer match between the skills students learn in school and the skills they will need upon leaving school. Schools are now expected to help students develop skills and competencies in real-life, "authentic" situations, and schools are expected to graduate students who can demonstrate these abilities - often by their performance on alternative assessments rather than summative evaluation

In assessment implementation, teachers need to be involved in the changes and need time to decide how best to change the strategies that they use with their students and to incorporate the changes into their practice. Changing learner outcomes and assessments without teacher input and buy-in often results in resistance to change or ineffective shortcuts to change (Corbett \& Wilson, 1991).

Instead of giving the students a task and measuring how well they do or how badly they fail, one can give the students the task and observe how much and what kind of help they need in order to complete the task successfully. In this approach the student is not assessed alone. Rather, the social system of the teacher and student is dynamically assessed to determine how far along it has progressed (Newman, Griffin, \& Cole, 1989)

Some argued that the use of assessment as a "motivator" and believe that the quality of the assessment information gained is jeopardized when teachers teach to the test (Mehrens \& Kaminski, 1989). Every assessment can assess only a sample of the content that the teacher has taught and the student has learned. If that sample adequately represents the total content and the technical quality of the assessment is high, we can infer that students who do well on the assessment also could do well on the remaining content that is not assessed. If teachers teach to the content on the test - ignoring the rest of the content domain - then we cannot make this inference and the utility of the assessment as a measure of the broader domain is lost.

\section{METHOD}

\section{Research design}

Descriptive survey research was used as the most relevant design for this study under consideration. As indicated by Best and Kahn(2003), descriptive study describes and interprets what conditions or relationship that exist, opinions that are held, processes that are going on, effects that are evident, or trends that are developing. In line with this design, mixed research approach (quantitative played the major role; and the qualitative took the supportive role to strengthen the information obtained through quantitative data).Mixed approach is preferred to complement, substantiate and triangulate the quantitative data analysis results with qualitative data gathered from key informants.

\section{Populations}

The population of interest for the study was Adana Science and Technology University teachers. A total of 496 participants was the target that has completed Higher Diploma Program (HDP) or pedagogical Skills and Improvement and Support for Teachers (PSIST) in 2009-2013. 


\section{Sampling and sampling Techniques}

In order to keep proportionality of the representative's, participants from tall schools, were proportionally sampled as indicated in the Table 1 below. The researchers used stratified sampling technique assuming proportional allocation. Accordingly, each school received relatively proportional number of respondents. Besides, interview respondents are taken to be used by Purposive sampling techniques due to their Plenty of experience in the training.

Table 1

Distribution of respondents

\begin{tabular}{lllllllll}
\hline & \multicolumn{7}{c}{ Number of Graduates in Years } \\
\hline S.N & Schools & 2009 & 2010 & 2011 & 2012 & 2013 & Popn & Sample \\
\hline 1 & Engineering & 12 & 37 & 39 & 46 & 15 & 149 & 30 \\
2 & Humanities, Law and Natural & 14 & 14 & 12 & 20 & 17 & 77 & 21 \\
& Sciences & 12 & 18 & 18 & 17 & 3 & 66 & 17 \\
3 & Business and Economics & 22 & 41 & 14 & 18 & 11 & 106 & 18 \\
4 & Agriculture & 17 & 32 & 25 & 15 & 9 & 98 & 25 \\
5 & Health Sciences & 77 & 142 & 108 & 116 & 55 & 496 & 111 \\
\hline & Grand Total &
\end{tabular}

The total sample is almost around $20 \%$, which is reasonable in such homogenous nature of training

\section{Data collection instruments}

To collect relevant data for the study, instruments were developed and employed based on Arnold (1991) professional development evaluation "training effectiveness" stage, and Armstrong (1996) and Kirkpatrick (1998) training evaluation stage assumption. Therefore, items for the questionnaires were adapted by the writers to link into pedagogical skills training condition. A questionnaire and interview are the two dominantly used instruments of data gatherings. All reliability and validity checks are undertaken through pilot testing, before instruments made to be used for actual data gatherings.

\section{Methods of data analysis}

The objective of the study was to describe the practices, impacts and challenges encountered in offering pedagogical skills training for teachers in supporting their teaching. To achieve the objective, all the data gathered through questionnaire was organized and classified using tables. Then, frequencies and percentages were used to describe practices and challenges of the training.

The qualitative part of the study employed open ended questions which follow categorization, and classifications. This method involves deep immersion into the data presented in the form of figures; working out the key issues, and concepts in order to properly examine the data; summarize opinion of the participants; and mapping and interpretation. 


\section{FINDINGS AND DISCUSSIONS}

The intention of this study was to understand the implementation of Pedagogical Skills Improvement program conducted in 2009-2013. The practices of teachers in the classroom will be emphasized from the perspectives of teaching quality for the betterments of students learning. In order to reach at conclusions, the following analysis was undertaken.

Table 2

Overall implementation of the training

\begin{tabular}{|c|c|c|c|c|c|c|c|}
\hline Category & & & Scale & & & & \\
\hline Overall Implementation of PSIST & $\mathrm{N}$ & $1(\mathrm{SD})$ & 2(D) & 3(UD) & $4(\mathrm{Ag})$ & 5(Str.Ag) & Total \\
\hline The training modules are well structured & 111 & $4 \%$ & $14 \%$ & $14 \%$ & $50 \%$ & $18 \%$ & $100 \%$ \\
\hline The training was implemented professionally & 111 & $4 \%$ & $14 \%$ & $19 \%$ & $45 \%$ & $18 \%$ & $100 \%$ \\
\hline The training received was implemented easily & 111 & $5 \%$ & $11 \%$ & $23 \%$ & $39 \%$ & $23 \%$ & $100 \%$ \\
\hline $\begin{array}{l}\text { The training was presented in a way to } \\
\text { enhance my engagement in the program and } \\
\text { instruction }\end{array}$ & 111 & $4 \%$ & $13 \%$ & $14 \%$ & $45 \%$ & $24 \%$ & $100 \%$ \\
\hline
\end{tabular}

Table 2 above revealed that almost all teachers responded that the training program has been presented to the trainers in astructured, organized and professional way. According to Brophy and Good (1974) in McKenzie \& Turbill (1999) a better understanding of teachers' belief system or conceptual base will significantly contribute to enhancing educational effectiveness. Similarly, Hargreaves and Fullan (1991) emphasis teachers thought process as the base for what teachers do in practice. It is what teachers think, what teachers believe and what teachers do at the level of the classroom that ultimately shapes the kind of learning. The teachers need to establish the best way to overcome the challenges especially on the challenges which involve their attitude and behavior towards their profession. The schools management council should also offer fair opportunities to all the teachers.

This implies teachers' beliefs and understandings about learning and teaching, their beliefs about the nature and purpose of the training, their current classroom practices, can change in the school culture of teaching as potential contributors to enhance learning quality. Thus, to enhance learning of students as a result of change in teaching a culture of engagement in training as a process is an essential and one component of teachers' activities.

Table 3

Quality of the training contents

\begin{tabular}{|c|c|c|c|c|c|c|c|}
\hline Category & & & Scale & & & & \\
\hline Contents Quality & $\mathrm{N}$ & $1(\mathrm{SD})$ & 2(D) & 3 (UD) & $4(\mathrm{Ag})$ & 5(S.Ag) & Total \\
\hline $\begin{array}{l}\text { The content presented in the PSIST was } \\
\text { important for me to improve my teaching }\end{array}$ & 111 & $3 \%$ & $4 \%$ & $9 \%$ & $56 \%$ & $29 \%$ & $100 \%$ \\
\hline $\begin{array}{l}\text { The content introduced in the PSIST was } \\
\text { informative for my teaching in lessons }\end{array}$ & 111 & $2 \%$ & $8 \%$ & $18 \%$ & $49 \%$ & $23 \%$ & $100 \%$ \\
\hline $\begin{array}{l}\text { The content that I learned in the PSIST was } \\
\text { easily modifiable for my class teaching in } \\
\text { lessons }\end{array}$ & 111 & $3 \%$ & $7 \%$ & $15 \%$ & $47 \%$ & $28 \%$ & $100 \%$ \\
\hline
\end{tabular}


As can be observed in Table 3 above, the contents incorporated were helped the trainees to improve the teaching skills, inform them what is missed in their teaching skills and helped them to adjust their teaching to the condition of the classroom lessons. It is believed that teachers are important resource in the teaching and learning process. Their training and utilization of relevant contents therefore requires critical consideration. This is due to changing demands on the new roles of teachers in the $21^{\text {st }}$ Century in meeting the needs of their students through selecting contents that can impact the learning of the their students.

Table 4

Methodological presentation of the training

\begin{tabular}{|c|c|c|c|c|c|c|}
\hline Category & & Scale & & & & \\
\hline Methodology of contents delivery & $\begin{array}{ll}N & 1 \text { (S.D) }\end{array}$ & 2(DA) & 3(UD) & $4(\mathrm{Ag})$ & $5(\mathrm{~S} . \mathrm{Ag})$ & Total \\
\hline $\begin{array}{l}\text { Content presentation moved from simple to } \\
\text { complex. }\end{array}$ & $1113 \%$ & $8 \%$ & $\begin{array}{l}11 \\
\%\end{array}$ & $\begin{array}{l}46 \\
\%\end{array}$ & $32 \%$ & $100 \%$ \\
\hline $\begin{array}{l}\text { Logical presentation of contents introduced in } \\
\text { the training }\end{array}$ & $1113 \%$ & $9 \%$ & $\begin{array}{l}24 \\
\%\end{array}$ & $\begin{array}{l}39 \\
\%\end{array}$ & $25 \%$ & $100 \%$ \\
\hline $\begin{array}{l}\text { The way contents presented in the training was } \\
\text { enjoyable. }\end{array}$ & $1115 \%$ & $10 \%$ & $\begin{array}{l}14 \\
\%\end{array}$ & $\begin{array}{l}45 \\
\%\end{array}$ & $26 \%$ & $100 \%$ \\
\hline $\begin{array}{l}\text { The way contents presented in the training was } \\
\text { professional. }\end{array}$ & $1113 \%$ & $10 \%$ & $\begin{array}{l}18 \\
\%\end{array}$ & $\begin{array}{l}53 \\
\%\end{array}$ & $16 \%$ & $100 \%$ \\
\hline $\begin{array}{l}\text { The way contents presented in the training was } \\
\text { encouraging. }\end{array}$ & $1112 \%$ & $10 \%$ & $\begin{array}{l}19 \\
\%\end{array}$ & $\begin{array}{l}54 \\
\%\end{array}$ & $15 \%$ & $100 \%$ \\
\hline
\end{tabular}

Table 4 above speaks about the significant role of the training facilitators played. The trainees believed that training facilitators fill the gap between what is expected from teachers with regard to pedagogical skills and their understanding of teaching methodology through their session and lesson delivery. Though there is difference among teachers, because of the support provided by the training center, all considered training facilitators as played crucially role in facilitating the sessions properly. They felt that without training facilitators who can assist the program at the training session, it is difficult to expect pedagogical skills will bring the desired effect in their teaching. Most importantly teachers questioned the quality of their activities that they think encouragement and making the training professional would improve it.

\section{IMPACTS OF THE TRAINING}

Under this part of the study, teachers reflected their responses based on the benefit they get from the training. These are lessons learned in teaching their subjects, how to apply active learning methods, students assessments, planning lessons, manage their classroom for instruction. 
Table 5

Perceived learning from the training

\begin{tabular}{|c|c|c|c|c|c|c|c|}
\hline Category & & Scal & & & & & \\
\hline Perceived Learning & $\mathrm{N}$ & 1 (SD) & 2(D) & $3(\mathrm{UD})$ & $4(\mathrm{Ag})$ & $5(\mathrm{~S} . \mathrm{Ag})$ & Total \\
\hline $\begin{array}{l}\text { After the training, I am motivated to implement } \\
\text { various instructional strategies in my teaching } \\
\text { lessons. }\end{array}$ & 111 & $2 \%$ & $13 \%$ & $14 \%$ & $42 \%$ & $29 \%$ & $100 \%$ \\
\hline $\begin{array}{l}\text { After the training, I feel confident that I can } \\
\text { interact with students in lessons. }\end{array}$ & 111 & $1 \%$ & $9 \%$ & $15 \%$ & $46 \%$ & $29 \%$ & $100 \%$ \\
\hline $\begin{array}{l}\text { After the training, I can provide an alternative } \\
\text { way to explain concepts in my subject matter }\end{array}$ & 111 & $3 \%$ & $10 \%$ & $14 \%$ & $49 \%$ & $25 \%$ & $100 \%$ \\
\hline $\begin{array}{l}\text { After the training, I can regularly have my } \\
\text { students work through real-life problems that are } \\
\text { of interest to them when it comes to teaching } \\
\text { lessons }\end{array}$ & 111 & $1 \%$ & $13 \%$ & $22 \%$ & $42 \%$ & $23 \%$ & $100 \%$ \\
\hline $\begin{array}{l}\text { After the training, I am aware of the necessity to } \\
\text { apply diverse instructional strategies to help my } \\
\text { students learn better. }\end{array}$ & 111 & $3 \%$ & $13 \%$ & $14 \%$ & $47 \%$ & $23 \%$ & $100 \%$ \\
\hline $\begin{array}{l}\text { After the training, I feel that I learned a lot of } \\
\text { useful information for my teaching in my subject }\end{array}$ & 111 & $3 \%$ & $8 \%$ & $15 \%$ & $49 \%$ & $25 \%$ & $100 \%$ \\
\hline
\end{tabular}

It is believed that learning leads change in behavior. As one can see from Table 5 above, majority of the trainees change their mind to create various instructional strategies, identified optional way of instruction, and working with students through instruction. As it is noted in the above Table $\mathrm{V}$, most instructors are moving from traditional approach to teaching to relatively acceptable modern ways of instruction. This is consistent with the idea of Darling-Hammond, (1998) who asserts that traditional approaches of teaching such as formal courses are criticized for their shortcomings of being unable to get teachers prepared for the new role of knowledge facilitator rather than knowledge transmitter.

Table 6

Active learning methods implementation

\begin{tabular}{|c|c|c|c|c|c|c|c|}
\hline \multirow{2}{*}{$\begin{array}{l}\text { Category } \\
\text { Methods Implementation }\end{array}$} & \multicolumn{6}{|c|}{ Scale } & \multirow[b]{2}{*}{ Total } \\
\hline & $\mathrm{N}$ & $1(\mathrm{SD})$ & 2(D) & 3 (UD) & $4(\mathrm{Ag})$ & $5(\mathrm{SAg})$ & \\
\hline $\begin{array}{l}\text { I provide an alternative explanation or example when } \\
\text { students are confused in my lessons }\end{array}$ & 111 & $4 \%$ & $5 \%$ & $12 \%$ & $50 \%$ & $31 \%$ & $100 \%$ \\
\hline $\begin{array}{l}\text { I adjust lessons to students who have different level of } \\
\text { understanding about contents presented. }\end{array}$ & 111 & $5 \%$ & $7 \%$ & $20 \%$ & $41 \%$ & $28 \%$ & $100 \%$ \\
\hline $\begin{array}{l}\text { I explain central themes in my lessons so that even the } \\
\text { low-achieving students understand them. }\end{array}$ & 111 & $1 \%$ & $5 \%$ & $16 \%$ & $47 \%$ & $31 \%$ & $100 \%$ \\
\hline $\begin{array}{l}\text { I provide good guidance and instruction to all students } \\
\text { regardless of their level of ability in my lessons. }\end{array}$ & 111 & $3 \%$ & $5 \%$ & $15 \%$ & $52 \%$ & $25 \%$ & $100 \%$ \\
\hline $\begin{array}{l}\text { I explain important concepts in lesson so that most } \\
\text { students understand the basic principles. }\end{array}$ & 111 & $4 \%$ & $4 \%$ & $12 \%$ & $59 \%$ & $23 \%$ & $100 \%$ \\
\hline $\begin{array}{l}\text { I implement teaching methods at an appropriate pace } \\
\text { to accommodate differences among my students. }\end{array}$ & 111 & $2 \%$ & $5 \%$ & $23 \%$ & $50 \%$ & $20 \%$ & $100 \%$ \\
\hline $\begin{array}{l}\text { I actively involve students in critical analysis and/or } \\
\text { problem solving }\end{array}$ & 111 & $3 \%$ & $9 \%$ & $14 \%$ & $47 \%$ & $27 \%$ & $100 \%$ \\
\hline I monitor students' involvement during learning tasks & 111 & $3 \%$ & $\%$ & $14 \%$ & $50 \%$ & $28 \%$ & $100 \%$ \\
\hline
\end{tabular}




\begin{tabular}{|c|c|c|c|c|c|c|c|}
\hline I adjust teaching and learning activities as needed & 111 & $2 \%$ & $5 \%$ & $18 \%$ & $46 \%$ & $29 \%$ & $100 \%$ \\
\hline $\begin{array}{l}\text { I involve students in developing higher order thinking } \\
\text { skills }\end{array}$ & 111 & $2 \%$ & $5 \%$ & $11 \%$ & $58 \%$ & $25 \%$ & $100 \%$ \\
\hline I motivate students to perform to their fullest potential & 111 & $2 \%$ & $5 \%$ & $13 \%$ & $55 \%$ & $26 \%$ & $100 \%$ \\
\hline $\begin{array}{l}\text { I Provide students with opportunities to learn at more } \\
\text { than one cognitive and/or performance level }\end{array}$ & 111 & $2 \%$ & $6 \%$ & $17 \%$ & $43 \%$ & $32 \%$ & $100 \%$ \\
\hline $\begin{array}{l}\text { I provide a learning environment that accommodates } \\
\text { students with special needs }\end{array}$ & 111 & $3 \%$ & $6 \%$ & $16 \%$ & $41 \%$ & $34 \%$ & $100 \%$ \\
\hline
\end{tabular}

Teacher's ability to apply what they gained during training is important part of the training. It was assumed that after training, teachers assist their students for better learning and understanding of their subject matter. Teachers are an important resource in the teaching and learning process and their training and utilization of varieties of methodologies. Therefore, it requires critical consideration.

Teaching in a class of 50 students requires a whole range of management and organizational skills if sufficient order necessary for pupils learning is to be maintained. The successful classroom organization and management requires teachers to keep attention and action between several activities to ensure that pupils learning proceed smoothly. The classroom climate established by the teacher can have a major impact on student's motivation and attitude towards learning. The chapter deals with how to make attractive classroom while teaching any subject at any level. Moreover, the chapter indicated some of the misbehaviours and the remedial techniques to have smooth and conducive classroom climate for the students learning.

The teachers role after the training is to increase desire to learn for his/her students. In the analysis the participants believed if students motivated they can do more and best in their education. In fact, one of the key factors could be the idea that teachers have to be motivated to engage fully to motivate his/ her students. The process of rewarding should help to distinguish between those students who perform the role well, and those who perform the role with excellence. As a professional, the teachers believe that the motivation in line with classroom performance on top of school performance, which will result in improved teaching and learning.

Table 7

Students' assessment

\begin{tabular}{|c|c|c|c|c|c|c|c|}
\hline \multicolumn{3}{|l|}{ Category } & \multicolumn{5}{|l|}{ Scale } \\
\hline Assessment & $\mathrm{N}$ & 1 (SD) & 2 (DA) & 3 (UD) & $4(\mathrm{Ag})$ & 5(S.Agr) & Total \\
\hline $\begin{array}{l}\text { I usually answer students questions in a way that } \\
\text { help students understand difficult topic or } \\
\text { problems }\end{array}$ & 111 & $8 \%$ & $2 \%$ & $13 \%$ & $52 \%$ & $25 \%$ & $100 \%$ \\
\hline $\begin{array}{l}\text { I use a variety of assessment strategies in my } \\
\text { lessons }\end{array}$ & 111 & $5 \%$ & $6 \%$ & $14 \%$ & $51 \%$ & $23 \%$ & $100 \%$ \\
\hline $\begin{array}{l}\text { I Provide students with specific feedback about } \\
\text { their learning }\end{array}$ & 111 & $1 \%$ & $11 \%$ & $14 \%$ & $51 \%$ & $23 \%$ & $100 \%$ \\
\hline $\begin{array}{l}\text { Solicit a variety of questions throughout the } \\
\text { lesson that enable higher order thinking }\end{array}$ & 111 & $7 \%$ & $5 \%$ & $14 \%$ & $53 \%$ & $22 \%$ & $100 \%$ \\
\hline
\end{tabular}


In a large class size, application of assessment technique could be one of the challenges in the current teaching learning process. In some instances, this could be attributed to the limit of teachers' skills in handling large class size. This study reveals that teachers are able to use assessment techniques by giving tasks and supporting with feedbacks that indicate students' progress after the training. Consistent with these findings (Newman, Griffin, \& Cole, 1989) noted that instead of giving the students a task and measuring how well they do or how badly they fail, one can give the students the task and observe how much and what kind of help they need in order to complete the task successfully.

Table 8

Planning

\begin{tabular}{|c|c|c|c|c|c|c|c|}
\hline Category & & & Scale & & & & \\
\hline Planning & $\mathrm{N}$ & $1(\mathrm{SD})$ & 2(D) & 3(UD) & $4(\mathrm{Ag})$ & $5(\mathrm{SAg})$ & Total \\
\hline $\begin{array}{l}\text { Plan activities that accommodate the range of } \\
\text { individual differences among my students. }\end{array}$ & 111 & $2 \%$ & $6 \%$ & $21 \%$ & $49 \%$ & $23 \%$ & $100 \%$ \\
\hline $\begin{array}{l}\text { Plan evaluation procedures that accommodate } \\
\text { individual differences among my students }\end{array}$ & 111 & $2 \%$ & $6 \%$ & $20 \%$ & $44 \%$ & $28 \%$ & $100 \%$ \\
\hline $\begin{array}{l}\text { Use allocated time for activities that maximize } \\
\text { learning }\end{array}$ & 111 & $2 \%$ & $4 \%$ & $15 \%$ & $54 \%$ & $25 \%$ & $100 \%$ \\
\hline $\begin{array}{l}\text { Effectively manager routines and procedures for } \\
\text { learning tasks }\end{array}$ & 111 & $3 \%$ & $3 \%$ & $18 \%$ & $52 \%$ & $24 \%$ & $100 \%$ \\
\hline Clarify directions for learning routines & 111 & $2 \%$ & $4 \%$ & $14 \%$ & $55 \%$ & $26 \%$ & $100 \%$ \\
\hline $\begin{array}{l}\text { Maintain high levels of student engagement in } \\
\text { learning tasks }\end{array}$ & 111 & $3 \%$ & $6 \%$ & $18 \%$ & $50 \%$ & $23 \%$ & $100 \%$ \\
\hline Redirect students who are persistently off task & 111 & $2 \%$ & $3 \%$ & $22 \%$ & $48 \%$ & $26 \%$ & $100 \%$ \\
\hline Maintain a classroom climate of courtesy and respect & 111 & $2 \%$ & $5 \%$ & $12 \%$ & $54 \%$ & $28 \%$ & $100 \%$ \\
\hline Maintain a classroom climate that is fair and impartial & 111 & $2 \%$ & $3 \%$ & $16 \%$ & $57 \%$ & $23 \%$ & $100 \%$ \\
\hline Communicate to students the specific learning & 111 & $2 \%$ & $1 \%$ & $15 \%$ & $57 \%$ & $25 \%$ & $100 \%$ \\
\hline
\end{tabular}

Table 8 above talks about the instructional planning. It is a planning usually carried out at instructional level by a classroom teacher for teaching different courses. In planning to know the details of the contents, method, and duration and analyse their parts in order to attain the desired educational objectives. The respondents confirmed that the planning considers individual difference, classroom management, allocation of time for their courses, relation between students and teacher engagement. Some experienced teachers draw their lesson plan from their teaching experiences over the years however; unexperienced ones have relatively little to draw upon, other than their text books. Novice teachers need assistance in deciding what objectives to strive for, what activities to include and which material to employ. It is the task of the university. 
Table 9

Satisfaction

\begin{tabular}{|c|c|c|c|c|c|c|c|}
\hline Category & & & Scale & & & & \\
\hline Satisfaction & $\mathrm{N}$ & $1(\mathrm{SD})$ & $2(\mathrm{D})$ & 3 (UD) & $4(\mathrm{Ag})$ & $5(\mathrm{~S} . \mathrm{Ag})$ & Total \\
\hline The contents of the training were what I expected. & 111 & $6 \%$ & $13 \%$ & $19 \%$ & $43 \%$ & $19 \%$ & $100 \%$ \\
\hline $\begin{array}{l}\text { I learned useful information from the training to } \\
\text { improve my teaching }\end{array}$ & 111 & $4 \%$ & $8 \%$ & $16 \%$ & $48 \%$ & $24 \%$ & $100 \%$ \\
\hline It was worth my time to take this training & 111 & $5 \%$ & $14 \%$ & $14 \%$ & $51 \%$ & $16 \%$ & $100 \%$ \\
\hline $\begin{array}{l}\text { I would recommend that other colleagues to take } \\
\text { this training to improve their teaching methods. }\end{array}$ & 111 & $5 \%$ & $9 \%$ & $8 \%$ & $47 \%$ & $32 \%$ & $100 \%$ \\
\hline $\begin{array}{l}\text { If there is another opportunity to take this type of } \\
\text { program, I will be willing to take it. }\end{array}$ & 111 & $8 \%$ & $11 \%$ & $14 \%$ & $35 \%$ & $32 \%$ & $100 \%$ \\
\hline Overall, I am satisfied with the training received. & 111 & $5 \%$ & $11 \%$ & $14 \%$ & $47 \%$ & $23 \%$ & $100 \%$ \\
\hline
\end{tabular}

Teaching is a tremendously exciting and rewarding job. This study did not attempt to indicate which activities motivate teachers and lead to their job satisfaction. However, it is specifically talks about the satisfaction level of teachers about the training received. As can be observed from the above Table 9, teachers were satisfied in the overall components of the program indicating that they were convinced to recommend the training for others. Consistent with the finding Csikszentmihalyi (1990) has proposed that individuals reach a state of happiness and satisfaction when they are involved in an activity and are functioning at the peak of their abilities. In this analysis, teachers involved in the training had acquired experiences of high levels of concentration, immersion, strength, and control in the training duration.

\section{The Challenges of the Pedagogical skills training}

In this study, there are issues that the respondents informed which necessarily needs attention and mentioned as challenges: these are redundancy of topic, words, and sayings, loose connection between contents of the different modules. Moreover, majority of the respondents said that the training program overlap with their regular classroom teaching, low financial motivation, inadequate resource supply, large class size, and absence of follow up during practical work, and poor working environment were some of the challenges.

\section{CONCLUSION}

Quality of teaching, the result of pre-service and in-service training, is the core in determining developmental nature of student's achievement (Lockheed and Verspoor, 1991). This study reveals that the current status of the training quality of the teachers lead to a better change of attitude towards professional development that better instruction and influence student learning and able to guide their work. The teachers involved in the study had no varying assumptions about professional skills they have received in general and its relevance in particular. In the quantitative analysis made in this study, majority of them (over 50\%) were agreed to rate the program is highly supportive in skills development and influenced their teaching skills. This implied that the utilization of professional skills training can contribute to the personal skills enhancement and productive workforce in the university academic community. 
However, some of them viewed as it is less supportive and while others had been in indifferent.

The research finding revealed that the majority of the respondents indicated factors in the training and some of these are redundancy of concepts, irrelevance of examples, in some schools the modules are not tailored to the respective disciple, English and IT modules do not satisfy the needs of the trainers. Moreover, factors that influenced teachers' implementation of PSIST are large class size, materials and facilities, lack of motivation, lack of recognition of the program were some among others. It can be concluded that when teachers do not have any kind of pedagogical training organized for any group under any circumstances, they might not be aware of better teaching practices and they might feel that they are not supportive to the students they are teaching so as to construct knowledge and skills.

\section{RECOMMENDATIONS}

- Teachers are important resource in the teaching and learning process and their professional skills training as well. In this study, the overall implementation of the program in all presented parameters is above average. Therefore, the current training of pedagogical skills requires critical consideration and support by all parties involved. These are the University management particularly the office of the Academic Vice President, Schools Deans', and Department Heads to recruit staff and make follow up their training.

- In this study, it is observed that respondents of all schools gave their comments about redundancy of activities, contents and concepts. To this end, organizations of the modules have to be reviewed for all schools.

- In the qualitative analysis part, majority of the respondents were not interested in receiving training of English and IT modules. This could be attributed to perhaps their background that almost all staff came through these two modules in their academic career. Therefore, skipping these two modules, considering into continuous professional development should be one of the action taken by concerned bodies in the university.

- Majority of the respondents in all schools gave feedback about the problem of large class size as a barrier to implement active learning, continuous assessment and action research. In order to increase the quality of student learning through implementation of active learning, the University should think how to balance intake capacity and resources, reducing intake capacity particularly in areas that needs sharing resources .

- Teachers have to be motivated to engage fully in professional and personal development. The university has to put pedagogical skill improvement program as a standard to get benefits, and the certificate has to get weight in staff promotion, pursue short term, further education, and even salary increment. The process of rewarding should help to distinguish between those who perform the role not well, and those who perform the role with high commitment.

- Regarding scarcity of resources, financial constraints, and incentives, the University must allocate separate budget based on the action plan presented from the training center. 


\section{REFERENCES}

Armstrong, A. (1996). The value of evaluating training and staff development,evaluation. News \& Comment, 5(2), 58-62.

Arnold, L. (1991). Internal evaluation: Building organization from within. Sage: California.

Bell, B., \& Gilbert, J.K. (1996). Teacher development: A model from science education. London: Falmer Press.

Best, J. W., \& Kahn, J. V. (2003). Research in education. Boston: Library of Congress.

Bond, L. A. (1992). Developing SCANS assessment measures: Issues and options. A paper written to guide the development of the assessment framework and assessment procedures for SCANS assessments. Iowa City, IA: American College Testing Program, and Washington, DC: Council of Chief State School Officers.

Bond, L. A., Herman, J., \& Arter, J. (1994). Rethinking assessment and its role in supporting educational reform. In Laboratory Network Program, A tool kit for professional developers: Alternative assessment. Portland, OR: Northwest Regional Educational Laboratory.

Boud, D., Keogh, R., \& Walker, D. (1985), Reflection, turning experience into learning. London: Kogan Page.

Brophy, J., \& Good, T. (1974). Teacher-student relationships: Causes and consequences. New York: Holt, Rinehart and Winston.

Clark, L. H., \& Star, I. S. (1996). Secondary and middle school teaching methods. Glewood Cliffs: Prentice Hall.

Corbett, H. D., \& Wilson, B. L. (1991). Testing, reform and rebellion. Norwood, NJ: Ablex Publishing Corporation.

Csikszentmihalyi, M. 1990. Flow: The psychology of optimal experience: New York: Harper and Row.

Darling-Hammond, L. (1998). Teachers and teaching: Testing policy hypotheses from a national commission report. Educational Researcher, 27(1), 5-15.

Dewey, J. (1933). How we think: A restatement of the relation of reflective thinking to the educative process. Lexington, MA: Heath.

Gibbs, G., \& Coffey, M. (2004). The impact of training of university teachers on their teaching skills, their approach to teaching and the approach to learning of their Students Active Learning in Higher Education, 5, 87-100.

Felder, R. M., \& R. Brent (2009). Active learning: An introduction. ASQ Higher Education Brief, 2(4). 
Hargreaves, A., \& Fullan, M. (1998). What's worth fighting for out there? New York: Teachers College Press.

Kirkpatrick, D. L. (1998). Evaluation training program: The four levels. Berrett-Koehler Publishers: San Francisc.

Klaver, K. J. (1984). Intentional and incidental learning with institutional texts. A metaanalysis for 1970-1980. American Educational Research Journal, 21, 323-340.

Kyriacou, C. (2001). Essential of teaching skills. United Kingdom: Nelson Thornes Ltd.

Linn, R. (1987). Accountability: The comparison of educational systems and the quality of test results. Educational Policy, 1(2), 181-198.

Lockheed, M. E., \& Verspoor, A. (1991). Improving quality of education in developing countries. New York: Oxford University Press.

Mckenzie, B., \& Trubill, J. (1999). Professional development, classroom practice and students out comes: Exploring the connection in early literacy development. Retrieved January 22, 2014, from http://www.aare.edu.au/99pap/mc k 99328.htm.

MOE (2009). Continuous professional development for primary and secondary school teachers, leaders and supervisors in Ethiopia: The framework. Ministry of Education: Ethiopia.

MOE (2010). Federal democratic republic of Ethiopia: Education sector development program. Addis Ababa: Ethiopia.

Nakabugo, M, Barrett, E., \& Munck, R. (2010). Best practice in North-South research relationships in higher education: The Irish African partnership model. Policy and Practice: A Development Education Review, 10, 89-98.

Newman, D., Griffin, P., \& Cole, M. (1989). The construction zone: Working for cognitive change in school. Cambridge: Cambridge University Press.

Postareff, L., Sari Lindblom-Yla“ nne, \& Anne N. (2007). The effect of pedagogical training on teaching in higher education. Journal of Science Direct: Teaching and Teacher Education, 23, 557-571.

Putnam, R., \& Borko, H. (2000). What do new views of knowledge and thinking have to say about research on teacher learning? Educational Researcher, 29(1), 4-15.

Reece, I., \& Walker, S. (2004). Teaching, training and learning. Great Britain: Business: Education Publishers Limited.

Robbins, S. (1984). Management concept and practice. New Jersy: Printice hall.

Scott, A. (2005). Active learning. UK: Peterborough.

Shepard, L. A. (1989). Why we need better assessments. Educational Leadership, 46(7), 4-9. 
UNESCO (1994). Salamanca statement and framework for action on special needs education. New York: UNESCO.

Villegas-Reimers, E. (2003). Teacher professional development: An international review of the literature. Paris: UNESCO

Winking, D., \& Bond, L. (1995). What you and your school should know about alternative assessment. Oak Brook: North Central Regional Educational Laboratory.

\section{Turkish Abstract \\ Adama Bilim ve Teknoloji Üniversitesi Pedagojik Becerileri Geliştirme Programının Etkileri ve Zorlukları}

$\mathrm{Bu}$ araştırma, üniversite eğitmenlerinin pedagojik beceri eğitimlerinin ASTU'daki öğretim öğeleri tarafından ölçülen öğretim yaklaşımları üzerindeki etkisi ile ilgilidir. Araştırmada betimsel tarama modeli yaklaşımı kullanılmıştır. Sonuçlar, pedagojik beceri eğitiminin, ders planlama, aktif öğrenme ve sürekli değerlendirme ve sınıf yönetimi konularındaki öğretim becerilerini etkilediğini ortaya koymuştur. Öğretmenler, sadece pedagojik eğitimin öğretim üzerindeki olumlu etkilerini değil, aynı zamanda kavramların, etkinliklerin ve örneklerin fazlalığı gibi zorlukları bildirerek; modüler, standart eğitimin süre, sınıf büyüklüğü, malzeme ve motivasyona bağlı olduğunu ancak, eğitimden elde ettiklerini tam olarak uygulayamadıklarını ifade etmişlerdir.

Anahtar Kelimeler: pedagoji, profesyonel uzmanlık becerileri, öğretim, eğitim

\section{French Abstract \\ Les Impacts et les Défis de Programme d'Amélioration de Compétences Pédagogique à Adama Science Et Université Technologique}

Ces rapports de recherche sont de l'impact des compétences pédagogiques des professeurs universitaires recevant une formation sur des approches à enseigner mesuré en enseignant des composants dans ASTU. La conception de recherche d'enquête descriptive a été employée. Les résultats ont indiqué que les compétences pédagogiques formant avaient un effet sur leurs compétences d'enseignement dans l'utilisation de la planification de leçon, l'apprentissage actif et l'évaluation continue et la gestion de salle de classe. Les professeurs ont mentionné les effets non seulement positifs de formation pédagogique sur leur enseignement, mais ont aussi informé quelques difficultés comme la redondance de concepts, d'activités, d'exemples; les modules ne sont pas à la durée standard, longue de la formation et la grande taille de classe, le manque de matériel et d'installations, le manque de motivation, l'incapacité de mettre en oeuvre entièrement ce qu'ils ont acquis de la formation.

Mots Clés: pédagogie, développement professionnel, compétences, enseignement, formation 


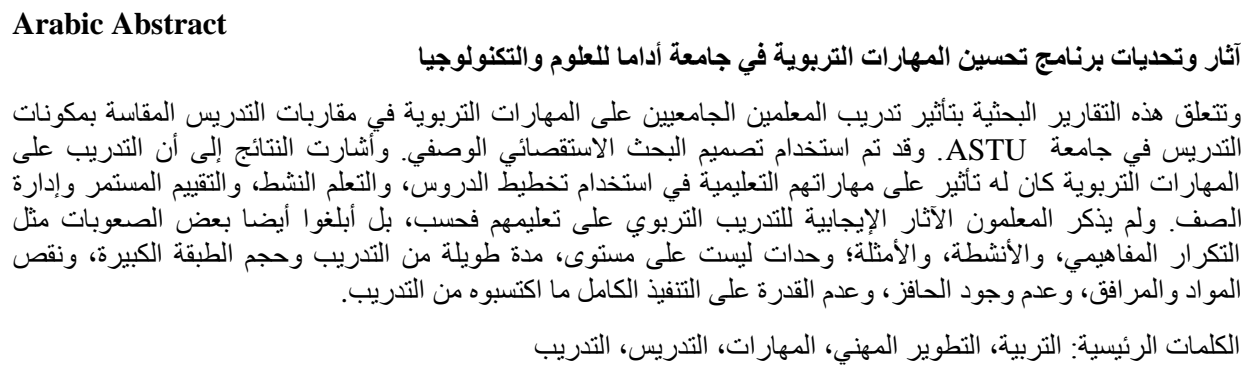

\title{
German Abstract
}

Die Auswirkungen und Herausforderungen der pädagogischen Fähigkeiten Verbesserung Programm bei Adama Wissenschaft Und Technologie Universität

Diese Forschungsberichte beruhen auf den Auswirkungen der pädagogischen Fähigkeiten der Hochschullehrer auf Lehrveranstaltungen, die durch Unterrichtsunterlagen in ASTU gemessen werden. Beschreibende Umfrage Forschung Design wurde eingesetzt. Die Ergebnisse zeigten, dass pädagogische Kompetenztraining Auswirkungen auf ihre Unterrichtsfähigkeit bei der Verwendung von Unterrichtsplanung, aktivem Lernen und kontinuierlicher Bewertung und Klassenzimmermanagement hatte. Die Lehrer nannten nicht nur positive Effekte der pädagogischen Ausbildung auf ihre Lehre, sondern auch einige Schwierigkeiten wie Redundanz von Konzepten, Aktivitäten, Beispielen; Module sind nicht auf den Standard, lange Dauer der Ausbildung und große Klassengröße, Mangel an Material und Einrichtungen, Mangel an Motivation, Unfähigkeit, voll zu implementieren, was sie aus dem Training erworben haben.

Schlüsselwörter: pädagogik, berufliche entwicklung, fertigkeiten, lehre, ausbildung

\author{
Malaysian Abstract \\ Impak dan Cabaran Program Penambahbaikan Kemahiran Pedagogi di Adama Science and \\ Technology University
}

Laporan kajian ini adalah tentang kesan latihan kemahiran pedagogi guru universiti terhadap pendekatan pengajaran yang diukur oleh komponen pengajaran di ASTU. Reka bentuk penyelidikan tinjauan deskriptif telah digunakan. Keputusan menunjukkan bahawa latihan kemahiran pedagogi mempunyai kesan ke atas kemahiran mengajar mereka dalam menggunakan perancangan pelajaran, pembelajaran aktif, dan penilaian berterusan dan pengurusan bilik darjah. Guru-guru tersebut tidak hanya memberi kesan positif tentang latihan pedagogi terhadap pengajaran mereka tetapi juga memaklumkan beberapa masalah seperti pengulangan konsep, aktiviti, contoh; modul bukan untuk standard, panjang latihan dan saiz kelas yang besar, kekurangan bahan dan kemudahan, kekurangan motivasi, ketidakupayaan untuk melaksanakan sepenuhnya apa yang mereka perolehi dari latihan.

Kata Kunci: pedagogi, pembangunan profesional, kemahiran, pengajaran, latihan 


\section{Russian Abstract}

Воздействие и Проблемы Педагогических Навыков Повышения Программы в Адам Науки и Техники Университете

Этот исследовательский отчет посвящен влиянию педагогических навыков обучения преподавателей университетов на подходы к обучению, измеренные с помощью учебных компонентов в АНТУ. Было разработано исследование описательных занятий. Результаты показали, что обучение педагогическим навыкам повлияло на преподавательские навыки при использовании планирования уроков, активного обучения, постоянной оценки и управления классами. Учителя отметили не только положительные результаты педагогической подготовки по обучению, но и сообщили о некоторых трудностях, таких как избыточность понятий, мероприятий, примеров; модули не соответствующие стандарту, длительности обучения и большому размеру класса, недостатку материалов и средств, отсутствию мотивации, невозможности полностью реализовать то, что они приобрели в ходе обучения.

Ключевые Слова: педагогика, профессиональное развитие, навыки, учение, обучение 